\section{Evolution and Entropy}

For an essay on "Evolution and Entropy" Mr. E. H. Betts has been awarded the Langhorne Orchard Prize of the Victoria Institute. The main thesis propounded is, that since in the author's opinion 'evolution' is contradicted by the law of entropy and the latter is beyond all question true, then 'evolution' is false or presumably has not taken place. The argument is put forward in a plausible manner and the essay makes interesting reading. What the author understands or means by 'evolution' is not at all clear, and sometimes he uses the word in the sense of change from simple to complex, sometimes it appears to have a moral, ethical or even religious meaning, and sometimes it is a striving towards perfection, whatever that may be. It is a relatively simple matter to endorse any of these points of view by quotations from some author or other, and then reduce to an absurdity or contradiction deductions that can be made from such quotations. Stress is laid on the difficulty of giving a logical statement of the derivation of living from non-living matter, but it seems equally clear that the law of entropy postulates the existence of matter capable of physical measurement but throws no light upon the origin of the matter itself. The ordinary mind has difficulty in imagining, let alone comprehending, that originally there was nothing, and then suddenly there was something; or the other alternative, that matter has always existed.

Mr. Betts suggests that in Nature and history the direction of progress is from complex to simple; presumably the organization of our society to-day is more simple than that of the ancient Britons. No biologist familiar with fossil faunas and floras would agree that this is true of the geological records of animals and plants. But perhaps all is well, for the author himself uses the sentence "Evolution itself thus rapidly evolved", and so employs a word which is extremely convenient to express the general idea that, in non-living as in living things, with the passage of time, a change or progression, so long as this is not intended to mean a movement limited to one direction, is, in fact, observable.

\section{Differential Fertility in Canada}

CANADA with its many wide spaces and farm lands has tended in the last few years to become more industrialized. It contains a large population of emigrants or the immediate descendants of emigrants from parts of Europe where tradition has influenced the reproductive tendencies of the people. For the future of Canada, which is under-populated, it is of some concern to understand the fertility of different groups of the population in order to supply information for policy-framing. Enid Charles (Canad. $J$. Econ. and Pol. Sci., 9, 175; 1943) presents an analysis of the differential fertility as seen in the 1931 census. The highest fertility is seen in Quebec and New Brunswick, the lowest in Ontario and British Columbia. There is high fertility among farmers, fishermen and food operatives, and low fertility among textile operatives, loggers, personal service workers, salesmen, owners and managers of manufacturing concerns. The late marriage of office workers and loggers could account for their low replacement birth-rate, while the small size of families of owners and managers accounts for the low fertility of these classes. Provincial differences contribute equally with occupational differences to fertility differences, while origin and religion of the individual are contributing causes. It is important to note that British Columbia, with a comparatively small population, is in reality urban in type-it has a high plane of living, a large majority of Protestants. The fertility is low. In a developing country like Canada, it should be possible to frame the policy and development of the country to encurage higher birth-rates in those sections of the community which are reduced, but it would seem that the Canadian population may tend to repeat the faults of several European countries unless a check is made by constructional legislation.

\section{Nature of the Viruses}

Prof. B. F. Osorio Tafall, National School of Biological Sciences, I. P. N., Mexico, has an article with the title "Naturaleza De Los Virus", in Ciencia of August 1943, which gives a very useful survey of the work done on viruses. While there is nothing added to our knowledge of the subject by this contribution, it provides an excellent historical review. and as it is written in a popular form, it will prove acceptable to many readers. Among the methods of studying viruses are ultra filters, colour tests (used to investigate psittacosis), photomicrography by ultra-violet light, the electron microscope, etc. New laboratory methods for diagnosing certain diseases caused by a virus which attacks both man and animals have been developed recently. Thus, Hertz described in 1942 how the allantois of the embryo of a chicken, when inoculated with the virus $A$ and $B$ of influenza, possesses the power of agglutinating the hæmatin, and this provides a simple test for detecting the virus of influenza in the throat and for determining the antibodies existing in the serum of the patient. The subject will be continued in a later issue of Ciencia.

\section{The Colombian Hypericum}

An article under the title "Algunos Chites Nuevos Colombianos" appearing in Ciencia of August 1943 (published in Mexico) deals with the Colombian chite, a plant belonging to the genus Hypericum. This genus comprises about three hundred known species which are distributed in the subtropical regions, being scarce in the temperate zones. Colombia has many forms of the plant and up to the present twenty-five speries have been found in the country. The author 'of the article, Jose Cuatrecasas, Escuela Superior de Agricultura Tropical, Cali, Colombia, acknowledges his indebtedness to Dr. Prittier, through whose kindness he has been enabled to study $H$. caracasanum. As a result of his investigations a number of previous identifications have been altered, and changes made regarding certain species and new varieties. Short descriptions are given of $H$. ruscoides, $H$. magniflorum, $H$. stenoclados, H. tamanum and $H$. lancioides.

\section{Earthquakes Registered in New Zealand and Spain}

DURING November 1943, seven strong earthquakes were registered by the seismographs at the New Zealand observatories. These were on November 2, 4, 6 (two), 13, 26 and 28. The shock of November 26, with an epicentral distance from. Wellington of about $83^{\circ}$, had a focal depth estimated between $130 \mathrm{~km}$. and $140 \mathrm{~km}$. In addition, nineteen earthquakes were felt in some part of New Zealand. The strongest three of these had intensity VI and were felt (1) on November 5 from Greymouth to Arthur's Pass, (2) on 
November 5 later in the day in the southern parts of North Island, and (3) on November 24 in the southwest parts of South Island.

In Spain during the same month, twenty-five earthquakes were registered by the seismographs at the Geophysical Observatory at Toledo. The earthquake of November 11 , registered at $22 \mathrm{~h}$. $57 \mathrm{~m}$. $51 \mathrm{~s}$. G.M.T., had an estimated epicentral distance from Toledo of $370 \mathrm{~km}$. and a focal depth of $25 \mathrm{~km}$. Its epicentre is likely to have been in the neighbourhood of lat. $37 \cdot 4^{\circ} \mathrm{N}$., long. $1 \cdot 7^{\circ} \mathrm{W}$., which is just west of the town of Aquilas on the Mediterranean coast of Spain. The earthquake was felt at Granada with intensity $V$.

\section{Study of Physical Medicine}

According to the Journal of the American Medical Association of December 25, the first centre for the scientific study and development of physical medicine as a branch of medical practice has been established by the National Foundation for Infantile Paralysis in the Graduate School of Medicine of the University of Pennsylvania. The centre will include a department for development of physical medicine as a scientific part of the practice of medicine, a training centre for medical leaders and teachers in this branch of medicine, and a school for training technical workers. The departments of anatomy, physiology pathology and other basic sciences of the University of Pennsylvania will co-operate in this proposed programme.

\section{The Chronica Botanica Co.}

THe Chronica Botanica Co., of Waltham, Mass., has issued a special edition of Dr. C. A. Browne's "Thomas Jefferson and the Scientific Trends of his Time" (an advance reprint from Chronica Botanica, 8) on the occasion of the tenth anniversary of its establishment. The Chronica Botanica Co. was founded in Leyden, the Netherlands, in September 1933, and was transferred to the United States early in 1940. An old, interesting, symbolic engraving, reproduced on an insert with the commemorative booklet, recalls the successful transfer of the firm's entire stock and its unique collection of source material in the history of botany and horticulture, just a few months before the invasion of the Low Countries. The firm, which is directed by Dr. Frans Verdoorn, publishes Chronica Botanica, "A New Series of Plant Science Books" and Annales Cryptogamici et Phytopathologici (formerly Annales Bryologici). Special projects in the course of preparation include: "Plants and Plant Science in Latin America" and the "Index Botanicorum".

\section{American Academy of Arts and Sciences Grants}

INCOME from the Permanent Science Fund of the American Academy of Arts and Sciences is used to support scientific research in the fields of mathematics, physics, chemistry, astronomy, geology, geography, zoology, botany, anthropology, psychology, sociology and economics, history and philology, engineering, medicine, surgery, agriculture, manufacture and commerce, education, or any other science of any nature or description. Equipment purchased outright through a grant from the Fund is subject to reassignment by the committee of award, upon termination of research in the particular field of endeavour in support of which a grant is made. Grants are not made for the financial support of work the results of which comprise partial fulfilment of requirements for an academic degree. It is a policy of the committee of award not to approve requests for general permanent equipment for institutions. Applications for grantsin-aid should be made on forms to be obtained from the chairman of the committee, and will be considered on June 1 and October 1. Communications should be addressed to John W. M. Bunker (chairman), Permanent Science Fund Committee, Massachusetts Institute of Technology, Cambridge 39, Massachusetts.

\section{Announcements}

The Executive Council of the Imperial Agricultural Bureaux has elected Mr. G. H. Creasy (Colonial Empire) as chairman in succession to Mr. Shamaldhari Lall (India). Lieut.-Colonel J. G. Robertson, representative on the Council of the Dominion of Canada, was elected vice-chairman.

The Colonial Office announces that Dr. E. E. Williams, of Trinidad, has been appointed secretary of the Agricultural Committee of the Caribbean Research Council. Dr. Williams, who has been assistant professor of social and political science at Howard University, Washington, has made a special study of economic problems in the British West Indies. He was born in 1911, and graduated at the University of Oxford.

The Secretary of State for the Colonies has decided, after consultation with the Governors of Northern Rhodesia and Nyasaland, to appoint a joint development adviser for the two territories, and Mr. G. F. Clay, director of agriculture in Uganda, has been appointed to the post. Mr. Clay has recently served as director of supplies for Uganda and director of native production for East Africa.

MaNy have been wondering how the gypsies have fared during the European War. After all, less than rnost folk are they concerned with the social and economic causes which have given rise to the present conflagration. The present issue of the Journal of the Gypsy Lore Society (23, pts. 1-2) contains the life and travels of Peter Lazarovic the Rudar, a vivid account of the story of an old gypsy who has had a chequered existence. There is also an interesting study of Esther Young, an English gypsy witch.

ThE annual report of the Board of Regents of the Smithsonian Institution for the year ended June 30, 1941, which has already been noted in NATURE (149, $326 ; 1942$ ), has now been issued as a bound volume (Washington, D.C. : Gov. Printing Office. 2 dollars) containing in a general appendix the customary miscellaneous selection of papers, some of them original, covering a wide range of scientific investiga tion and discussion. This appendix runs to some 450 pages. Among the papers not previously published elsewhere are those by E. P. Walker on "Care of Captive Animals"; F. C. Craighead on "The Influence of Insects on the Development of Forest Production and Forest Management", and F. C. Chase on "Useful Algæ". A number of others, such as those of H. C. Hottel on "Artificial Converters of Solar Energy" ; J. W. Lasley, jun., on "Mathematics and the Sciences"; H. E. Munsell on "Vitamins and their Occurrence in Foods"; and W. N. Fenton on "Contacts between Iroquois Herbalism and Colonial Medicine", are now made more accessible to scientific workers. 